\title{
PRF thermometry during MR-guided focused ultrasound ablation in a preclinical thiel model
}

\author{
loannis Karakitsios ${ }^{*}$, Martin Rube, Osnat Dogadkin, Senay Mihcin, Timur Saliev, Andreas Melzer \\ From Current and Future Applications of Focused Ultrasound 2014. 4th International Symposium \\ Washington, D.C, USA. 12-16 October 2014
}

\section{Background/introduction}

Proton Resonance Frequency (PRF) MR Thermometry is a useful method for treatment planning with MR-guided Focused Ultrasound (MRgFUS), as it provides accurate, real-time temperature maps. Thiel is an embalming medium that retains physical properties and life-like characteristics of human and animal tissue. The aim of the present study was to determine the accuracy of PRF Thermometry during MRgFUS and to estimate the value of PRF coefficient of pre-clinical Thiel embalmed human and animal tissue, and compare to fresh tissue and gel phantom.

\section{Methods}

PRF Thermometry was conducted on Thiel embalmed human and animal liver during MRgFUS treatment on a FUS system (ExAblate 2000, InSightec, Tirat Carmel, Israel) embedded on a $1.5 \mathrm{~T}$ scanner (Signa HDx, GE
Medical Systems, Milwaukee, USA). The temperature rise based on PRF Thermometry during treatment was compared to the actual temperature increase measured by fibre optic thermocouples. To calculate the PRF shift coefficient, we applied phase-referenced PRF thermometry during cooling of the tissue, to obtain a series of phase difference, $\Delta \Phi$ maps (Figure 1). The temperature difference, $\Delta \mathrm{T}$, was measured by thermocouples. The PRF shift coefficient was calculated from the measured $\Delta \Phi, \Delta \mathrm{T}$ (Figure 2).

\section{Results and conclusions}

We found that the temperature differences and the PRF coefficient were higher for the Thiel organs than for fresh organs. This leads to the assumption that embalming a tissue with Thiel fluid can affect PRF Thermometry. The chemical composition of the Thiel fluid and the electrical conductivity might be some possible reasons for

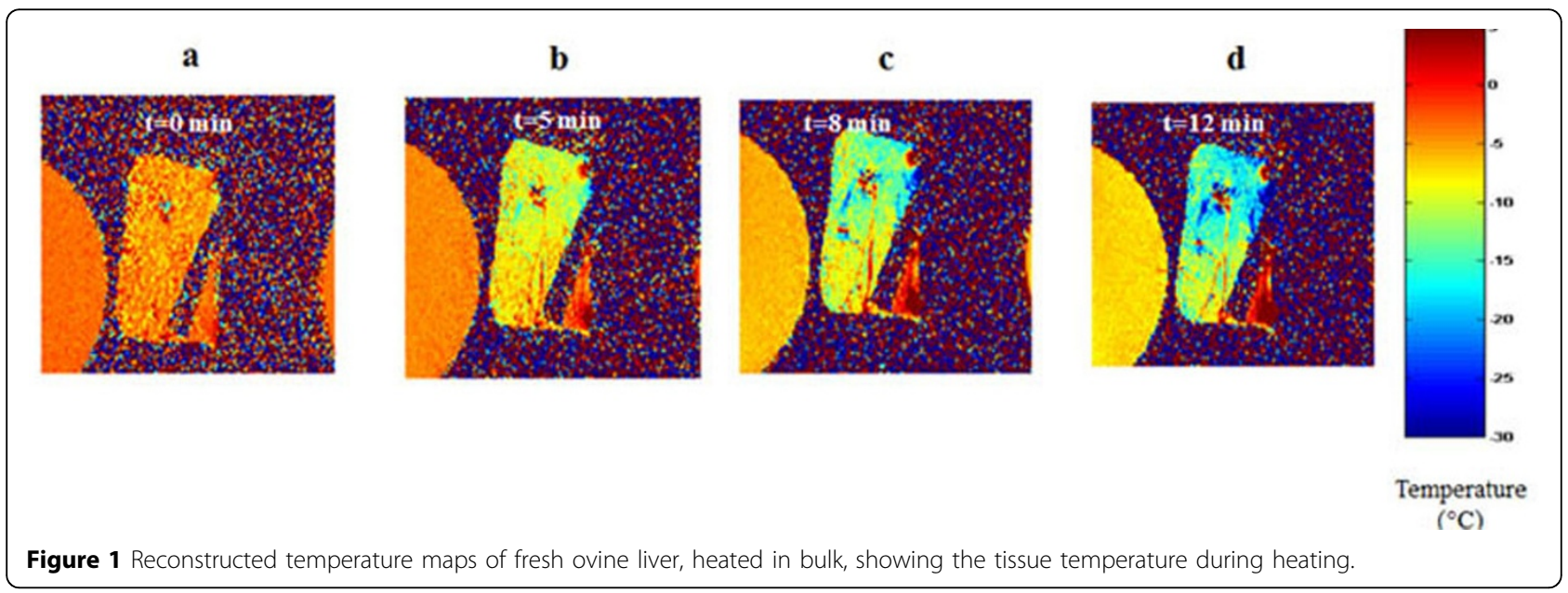

University of Dundee, Dundee, United Kingdom 

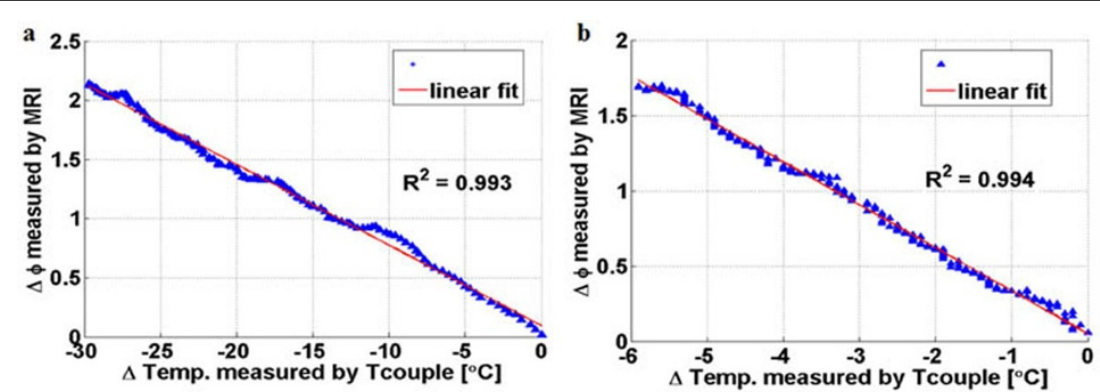

Figure 2 Example of graphs of the phase difference plotted as a function of temperature difference for: (a) bulk heating and (b) FUS-induced heating of Thiel embalmed human liver.

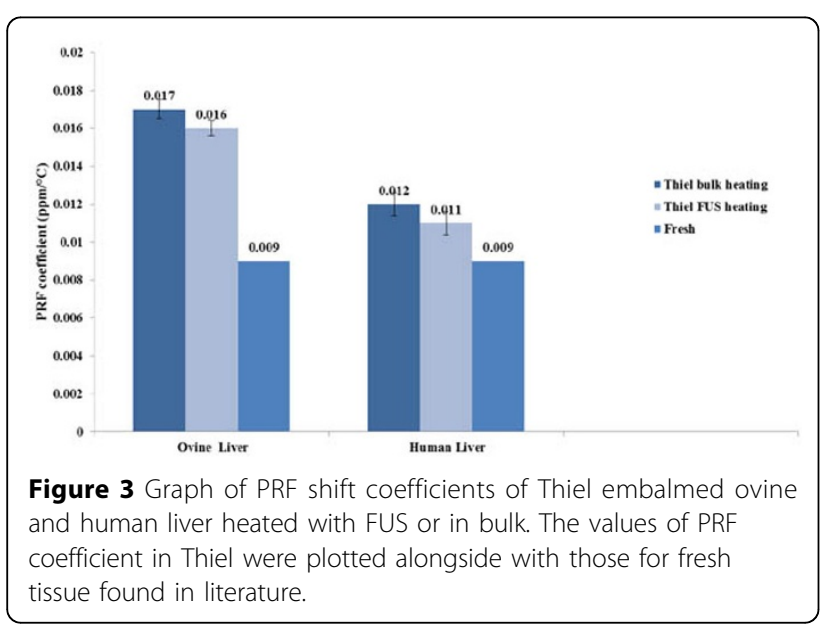

that. For the Thiel embalmed organs, we found temperature difference varying from $1.17 \mathrm{C}$ to $3.13 \mathrm{C}$ for ovine liver, and from $1.3 \mathrm{C}$ to $3.1 \mathrm{C}$ for human liver. For fresh tissue and phantom they were less than $0.4 \mathrm{C}$. In the case of bulk heating, average values of PRF coefficient $( \pm \mathrm{SD})$ were $0.016(4 \times 10-4) \mathrm{ppm} / \mathrm{C}, 0.011(5 \times 10-4) \mathrm{ppm} / \mathrm{C}$ for Thiel embalmed ovine liver and human liver, respectively (Figure 3).

\section{Acknowledgements (Funding)}

The authors are thankful for financial assistance provided by the project FUSIMO ("Patient specific modelling and simulation of focused ultrasound in moving organs") funded under the EU's Seventh Framework Programme for Research and Technological Development. We would also like to thank Dr. Roos Eisma from CAHID project and Mrs. Helen McLeod for providing us with Thiel embalmed human tissue.

Published: 30 June 2015

doi:10.1186/2050-5736-3-S1-P49

Cite this article as: Karakitsios et al:: PRF thermometry during MR-guided focused ultrasound ablation in a preclinical thiel model. Journal of Therapeutic Ultrasound 2015 3(Suppl 1):P49.

\section{Submit your next manuscript to BioMed Central} and take full advantage of:

- Convenient online submission

- Thorough peer review

- No space constraints or color figure charges

- Immediate publication on acceptance

- Inclusion in PubMed, CAS, Scopus and Google Scholar

- Research which is freely available for redistribution 